\title{
RESEARCH
}

Open Access

\section{Performance of concrete beams partially/ fully reinforced with glass fiber polymer bars}

\author{
Mohamed S. Moawad ${ }^{1 *}$ (D) and Ahmed Fawzi ${ }^{2}$
}

\author{
* Correspondence: m.moawad@fief. \\ edu.eg \\ ${ }^{1}$ Department of Structural \\ Engineering, Faculty of Engineering, \\ Future High Institute of Engineering \\ (FIEF), Fayoum, Egypt \\ Full list of author information is \\ available at the end of the article
}

\begin{abstract}
One of the major advantages of using glass fiber-reinforced polymer bars as a replacement to the traditional steel-reinforced bars is its lightweight and high-resistant to corrosion. This research focuses on the performance of concrete beams partially/fully reinforced with glass fiber-reinforced polymer bars with 50\% of GFRP bars were used to reinforce partially concrete beams at flexural zone. While 100\% of GFRP bars were used to reinforce fully concrete beams at flexural and compression zones with different concrete compressive strength.

This study reported the test results of 6 reinforced concrete beams with dimensions $150 \times$ 200 $\mathrm{mm}$ and a 1700-mm clear span length subjected to a four-point loading system. The tested beams were divided into three groups; the first one refers to the glass fiber-reinforced polymer bar effect. The second group is referring to the effect of concrete compressive strength, while the third group is referring to the effect of the GFRP bar volume ratio. Using longitudinal GFRP bars as a full or partial replacement of longitudinal steel bar reinforcement led to an increase in the failure load capacity and the average crack width, while a decrease in ductility was reported with a lower number of cracks. Increasing the concrete compressive strength is more compatible with GFRP bar reinforcement and enhanced the failure performance of beams compared with normal compressive strength concrete.
\end{abstract}

Keywords: Reinforced concrete beam, Glass fiber-reinforced concrete beams, Glass fiber bars, Cracking behavior, Ductility

\section{Introduction}

Glass fiber-reinforced polymer bar is one of the alternatives presented to overcome the defects related to the steel bars in specific reinforced concrete structural members. One of the most common problems in reinforced concrete structures is the corrosion of steel bars which reduces the lifetime of reinforced concrete structures. Consequently, using GFRP bars can delay the deterioration of a structure and improve its durability.

(c) The Author(s). 2021 Open Access This article is licensed under a Creative Commons Attribution 4.0 International License, which permits use, sharing, adaptation, distribution and reproduction in any medium or format, as long as you give appropriate credit to the original author(s) and the source, provide a link to the Creative Commons licence, and indicate if changes were made. The images or other third party material in this article are included in the article's Creative Commons licence, unless indicated otherwise in a credit line to the material. If material is not included in the article's Creative Commons licence and your intended use is not permitted by statutory regulation or exceeds the permitted use, you will need to obtain permission directly from the copyright holder. To view a copy of this licence, visit http://creativecommons.org/licenses/by/4.0/. The Creative Commons Public Domain Dedication waiver (http://creativecommons.org/publicdomain/zero/1.0/) applies to the data made available in this article, unless otherwise stated in a credit line to the data. 
GFRP bars have a high tensile strength to weight ratio [1-5], high performance against fatigue properties, non-conductivity, and electromagnetic resistance. In addition-as a major advantage-their thermal expansion coefficient is close to that of concrete [6-8].

GFRP bars present design challenges which are different than those in the design of traditional reinforced concrete. One major challenge is related to the brittle failure mode of GFRP-reinforced members [9].

Issa et al. [10] reported that the GFRP reinforcing bars have a relatively low modulus of elasticity, low ductility, and low stiffness when compared to traditional steel. This reduced stiffness, combined with other factors like a different bond behavior and lower tension stiffening, results in deflections that are larger than traditional steel-reinforced members at any stage of load. Because of these large deflections, structural designs may be governed by deflection limitations [9].

Many researchers now consider fiber-reinforced polymer (FRP) bars as an efficient and economical method to overcome the corrosion problems inherent to steel rebars in harsh environments. But, definitely, the absence of guidelines performance of GFRP bar-reinforced members is one of the major disadvantages to use GFRP bars as a replacement of steel bars. So, this research was investigated that the performance of concrete beam-reinforced partially/fully glass fiber polymer bars with/without traditional steel bars reinforcement.

Chin et al.[11] reported that the performance of concrete beams reinforced with overreinforced GFRP bars is safe for design in terms of deformability, and the behavior of beams reinforced by GFRP bars is bilinearly elastic until failure. In addition, its stiffness was found to be reduced after crack initiation when compared to the concrete beams reinforced with traditional steel bars.

D. T. C. Johnson [12] evaluated the GFRP reinforcement for its suitability as reinforcement for concrete structures and based on the research results, the GFRP stirrups reached stresses that exceeded the minimum design limits. The increased stirrup strength led to overall beam strengths that exceeded the estimated values based on code design provisions.

The investigation of the flexural behavior of high-strength concrete and ultra-strength concrete for beams reinforced with GFRP bars showed that bending stiffness decreases once cracking occurred [13]. A little influence was observed on increasing the postcracking bending stiffness for the same amount of longitudinal GFRP reinforcement, and a negligible effect was also reported on increasing cracking load.

Seongeun Kim and Seunghun Kim [14] concluded that the use of FRP bars and traditional steel bars as a flexural reinforcement leads to an increase in the failure load capacity of beams.

Yang et al. [15] investigated the behavior of concrete beams reinforced by a combination of different types of bars and determining solutions to many shortcomings of FRP-reinforced beams. They conducted a total of 10 experiments and analyzed the behavior related to post-cracking rigidity, crack patterns, ductility, and deflection. It was concluded that using combined reinforcement could control large deflections, deep cracks, and reduce the cracks' width.

Moon et al. [16] used a finite element analysis program to investigate the effects of the design variables of concrete beams reinforced with FRP bars. The flexural behavior of the beams was analyzed and the convenience of the analysis model was 
verified by comparing its results to previous experimental results. Reinforcement ratio, modulus of elasticity of FRP bars, and the compressive strength of concrete were the manipulated variables to investigate their effects on the flexural rigidity of the members and the deflection. Experimental results were compared to the provisions of the ACI 440. The study results indicated that the behavior was mostly affected by the reinforcement ratio, in addition to the increase in the compressive strength of concrete.

Karayannis et al. [17] studied behaviors of seven concrete beams reinforced with carbon FRP bars, and the experimental results show that the use of CFRP bars can be changed the modes of failure from pure flexural to failure in shear at high ratios of CFRP reinforcement. Brittle failure, decreasing in the number of cracks with larger cracks' width, and low initial cracks of beam specimen CFRP reinforcement were reported. And from it, the comparison between CFRP beams and GFRP beams of the flexural stiffness of CFRP-beam is higher than of the flexural stiffness of GFRP beam reinforcement.

Hemn et al. [18] investigated that the flexural capacity and behavior of geopolymer concrete beam reinforced by GFRP bars, and they concluded that the decrease in GFRP reinforcement ratio leads to an increase in ultimate load capacity and decreasing deflection.

\section{Methods}

\section{Aim of the study}

Many researchers now consider fiber-reinforced polymer (FRP) bars as an efficient and economical method to overcome the corrosion problems inherent to steel rebars in harsh environments. This experimental program aimed to study the effect of using the glass fiber-reinforced polymer bars as a full and partial longitudinal reinforcement for concrete beams.

The fundamental objective of this research paper is to study the flexural behavior of concrete beams reinforced with GFRP beams and its effect on the ductility, performance, durability, and serviceability of concrete beams.

\section{Experimental program}

The experimental program consisted of six reinforced concrete beams divided into two groups based on the characteristic concrete compressive strength. Each group included one control specimen reinforced with steel bars, while the other two specimens were fully and partially reinforced with GFRP bars. All specimens were loaded up to failure under the 4-point flexure test.

Table 1 Concrete mix design

\begin{tabular}{llllll}
\hline Mix & Cement $(\mathbf{k g})$ & Sand $(\mathbf{k g})$ & Dolomite $\mathbf{( k g )}$ & w/c ratio & Admixture $(\%)$ \\
\hline 1 & 370 & 660 & 1194 & 0.4 & 0.0 \\
2 & 500 & 693 & 1040 & 0.28 & 1.2 \\
\hline
\end{tabular}




\section{Materials and mix design}

Concrete Two concrete mixes were designed to achieve an average characteristic compressive strength of $30 \mathrm{MPa}$ and $60 \mathrm{MPa}$ as shown in Table 1. A superplasticizer admixture (sikament-163 M) was used to produce high-strength concrete. The admixture complies with ASTM C494 [1, 2]. To control the quality of the concrete mix, three cubes were randomly poured from the same batches of the beams and then tested. Table 2 is summarizing the cube's data and the corresponding failure load and characteristic compressive strength $[3,4]$.

Reinforcing bars Steel and GFRP reinforcement bars were used to reinforce concrete beams. Deformed high-grade steel bars of $10-\mathrm{mm}$ diameter, with 370MPa yield strength, and mild steel bars of 8-mm diameter with 240MPa yield strength were used as traditional beam reinforcement.

The used GFRP bars were locally fabricated by the pultrusion of E-glass continuous fibers and thermosetting polyester resin. To improve the bond characteristics of the bars, their surfaces are wrapped with helical glass fiber strands as well as; GFRP lower and upper reinforcement bars were bent at ends of beams specimens by $90^{\circ}$ as shown in Fig. 1. The GFRP bars used in this study are $8 \mathrm{~mm}$ and10 $\mathrm{mm}$ in diameter.

All samples were tested in direct tension at the Housing and Building National Research Center's laboratory. A $100 \mathrm{kN}$ testing machine was used to conduct all tensile testing. The machine is equipped with hydraulic grips and a stroke capacity of $75 \mathrm{~mm}$ in either direction. Direct clamping onto the GFRP bars at the ends would crush the fiber under high pressure. So, the tensile test results are incorrect. As a result, metal couplers were adhered to on the ends of the tested GFRP bars. And for the straight tested GFRP bars, the couplers were attached using master brace ADH 2200 twocomponent epoxy. Specimens were mounted into the hydraulic grips.

Mechanical properties of steel and GFRP bars are listed in Tables 3 and Table 4, respectively. Steel couplers were attached to the GFRP samples using epoxy while being

Table 2 Concrete compressive strength

\begin{tabular}{|c|c|c|c|c|c|c|c|c|}
\hline \multirow{2}{*}{$\begin{array}{l}\text { Concrete } \\
\text { type }\end{array}$} & \multirow{2}{*}{\multicolumn{2}{|c|}{$\begin{array}{l}\text { Sample } \\
\text { (ID) }\end{array}$}} & \multirow{2}{*}{$\begin{array}{l}\text { Weight } \\
\text { (kg) }\end{array}$} & \multicolumn{3}{|l|}{ Dimension } & \multirow{2}{*}{$\begin{array}{l}\text { Failure } \\
\text { load } \\
(\mathrm{KN})\end{array}$} & \multirow{2}{*}{$\begin{array}{l}\text { Fcu } \\
(N / \\
\left.\mathrm{mm}^{2}\right)\end{array}$} \\
\hline & & & & Length (mm) & Width (mm) & Height $(\mathrm{mm})$ & & \\
\hline \multirow[t]{6}{*}{ N.S.C } & I & 1 & 8248 & 150 & 150 & 150 & 814 & 36.17 \\
\hline & & 2 & 8210 & 152 & 151 & 152 & 777 & 33.85 \\
\hline & & 3 & 8388 & 152 & 151 & 151 & 795 & 34.62 \\
\hline & $\|$ & 1 & 8777 & 154 & 154 & 154 & 777 & 32.76 \\
\hline & & 2 & 8385 & 151 & 152 & 151 & 754 & 32.85 \\
\hline & & 3 & 8160 & 151 & 149 & 149 & 790 & 35.11 \\
\hline \multirow[t]{6}{*}{ H.S.C } & III & 1 & 8115 & 152 & 150 & 151 & 1631 & 71.53 \\
\hline & & 2 & 8270 & 153 & 149 & 150 & 1354 & 59.39 \\
\hline & & 3 & 7996 & 152 & 148 & 148 & 1211.2 & 53.84 \\
\hline & IV & 1 & 7975 & 149 & 149 & 149 & 1401.6 & 63.13 \\
\hline & & 2 & 7957 & 151 & 147 & 152 & 1599.1 & 72.04 \\
\hline & & 3 & 7897 & 151 & 147 & 149 & 1580.4 & 71.19 \\
\hline
\end{tabular}




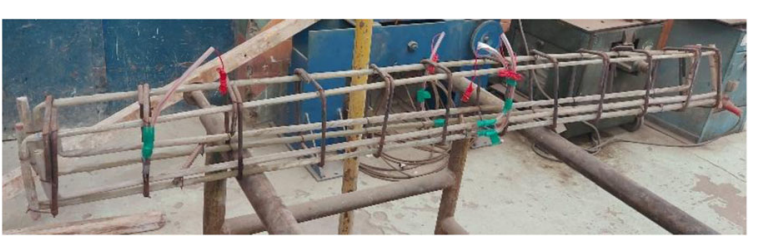

Fig. 1 Form of GFRP bar reinforcement

tested in direct tension because clamping directly to the GFRP bar at the ends would crush the fibers under high pressure rendering the tests inaccurate. Couplers were made from modified cut sections of steel pipes as shown in Fig. 2.

GFRP bars have a characteristic tensile strength and modulus of elasticity of $690 \mathrm{MPa}$ and $41 \mathrm{GPa}$, respectively. According to test results of the ultimate tensile strength of GFRP bar specimens, GFRP bar specimens' specifications meet ECP-208-2005 provisions.

\section{Specimens details}

Dimensions of all reinforced concrete beams were $150 \mathrm{~mm}$ width, $200 \mathrm{~mm}$ depth, and $1700 \mathrm{~mm}$ length with a clear span of $1500 \mathrm{~mm}$. Stirrups were designed to guarantee flexural failure of specimens. Typical specimen detailing is shown in Fig. 3, while Table 5 shows the reinforcement details for each specimen.

\section{Test setup and instrumentation}

The beams were simply supported over two rigid supports, as shown in Fig. 4, with a 1500-mm clear span. Specimens were tested using a hydraulic jack attached to a load

Table 3 Mechanical properties of steel reinforcement bars

\begin{tabular}{|c|c|c|c|c|c|c|}
\hline $\begin{array}{l}\text { Bar } \\
\text { size }\end{array}$ & $\begin{array}{l}\text { Unit weight }(\mathrm{kg} / \\
\left.\mathrm{m}^{\prime}\right)\end{array}$ & $\begin{array}{l}\text { Yield strength, } R_{\mathrm{eH}} \\
\left(\mathrm{N} / \mathrm{mm}^{2}\right)\end{array}$ & $\begin{array}{l}\text { Tensile strength, } R_{\mathrm{m}}(\mathrm{N} / \\
\mathrm{m}^{2} \text { ) }\end{array}$ & $\begin{array}{l}R_{\mathrm{m}} / \\
R_{\mathrm{eH}}\end{array}$ & $\begin{array}{l}\text { Elongation } \\
\%\end{array}$ & $\begin{array}{l}\text { Bend } \\
\text { test }\end{array}$ \\
\hline \multirow[t]{10}{*}{$8 \mathrm{~mm}$} & 0.399 & 275 & 429 & 1.56 & 17.5 & Pass \\
\hline & 0.400 & 273 & 428 & 1.57 & 18.9 & Pass \\
\hline & 0.399 & 279 & 434 & 1.56 & 18.3 & Pass \\
\hline & 0.402 & 275 & 426 & 1.55 & 18.5 & Pass \\
\hline & 0.403 & 257 & 408 & 1.59 & 17.5 & Pass \\
\hline & 0.400 & 287 & 421 & 1.47 & 16.1 & Pass \\
\hline & 0.401 & 264 & 402 & 1.52 & 17.8 & Pass \\
\hline & 0.401 & 275 & 436 & 1.59 & 15.8 & Pass \\
\hline & 0.398 & 278 & 431 & 1.55 & 16.3 & Pass \\
\hline & 0.395 & 314 & 440 & 1.40 & 18.8 & Pass \\
\hline \multirow[t]{6}{*}{$10 \mathrm{~mm}$} & 0.608 & 380 & 560 & 1.47 & 12.5 & Pass \\
\hline & 0.609 & 375 & 556 & 1.48 & 13.4 & Pass \\
\hline & 0.605 & 390 & 536 & 1.41 & 13.9 & Pass \\
\hline & 0.610 & 380 & 532 & 1.40 & 12.7 & Pass \\
\hline & 0.607 & 374 & 525 & 1.40 & 13.6 & Pass \\
\hline & 0.608 & 381 & 530 & 1.39 & 12.9 & Pass \\
\hline
\end{tabular}


Table 4 Mechanical properties of GFRP bars

\begin{tabular}{llll}
\hline Bar size & Diameter $(\mathbf{m m})$ & Modulus of elasticity (Gpa) & Tensile strength (Mpa) \\
\hline $8 \mathrm{~mm}$ & 8.1 & 40 & 330.88 \\
& 7.64 & 39 & 347.94 \\
& 7.63 & 41 & 334.88 \\
& 6.85 & 38 & 344.85 \\
$10 \mathrm{~mm}$ & 9.99 & 41 & 407.05 \\
& 10.8 & 43 & 405 \\
& 9.17 & 40 & 406 \\
& 9.64 & 45 & 400 \\
\hline
\end{tabular}

cell with a capacity of $1000 \mathrm{kN}$ under load control with increments of $10 \mathrm{kN}$ up to failure. The load was applied vertically at the center of the rigid steel beam which transmitted the load equally on two bearings resting on the top of the beam and spaced at $500 \mathrm{~mm}$.

Deflections were measured using linear variable transducers (LVDT); one LVDT was used to determine deflections at midspan of the beam, while two LVDTs were attached to the beams' bottom near the supports to check for any support movement while recording initial readings. Strain in the reinforcement was measured using strain gauges attached directly to the rebars as shown in Fig. 5. The measured data were recorded by a data logger connected to the computer system program "lab view" software.

\section{Results}

\section{Crack pattern and failure mode}

Figure 8 shows the typical modes of failure of the tested beam and the crack patterns for all tested beam specimens. All specimens were subjected to a 9-point loading system up to failure, and the cracks were observed and marked continuously during the loading time. In general, crack pattern and failure modes for specimens of the same reinforcing materials were found to be similar for different concrete compressive strengths.

Generally, for the two control specimens reinforced with traditional steel rebars (B1 and B4), flexural cracks at midspan following diagonal shear cracks were observed to appear and propagate throughout the beam length starting from the first crack till failure. A ductile failure was reported for these beams indicating the yield of the tension steel reinforcement which was proved by increasing the deflection prior to failure without an increase in the load. And the number of cracks was almost the same. And a brittle failure was observed for specimens B2 and B5 (fully reinforced with GFRP bars) and

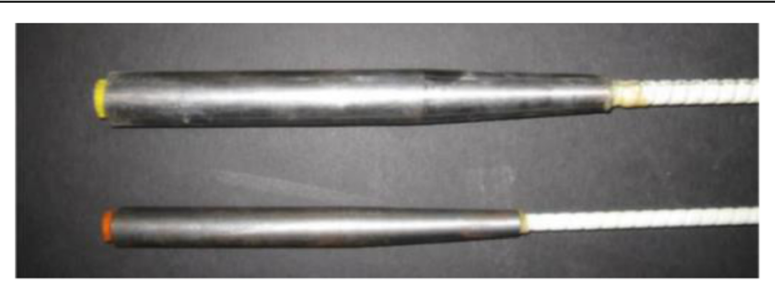

Fig. 2 Couplers used in tensile testing of GFRP bar specimens 


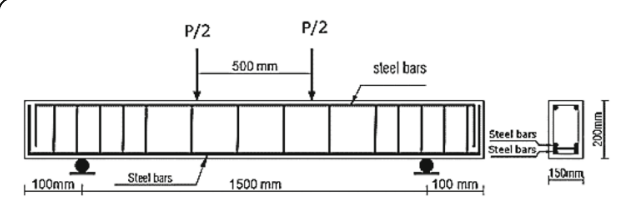

a: Typical fully reinforcement steelbars

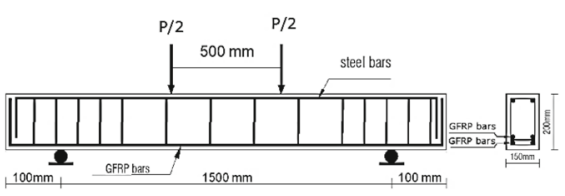

b: typical fully reinforcement GFRP bars

Fig. 3 Typical reinforcement detailing of tested beams. a Typical fully reinforcement steel bars. b Typical fully reinforcement GFRP bars

also for specimens B3 and B6 (partially reinforced with GFRP bars). Flexural cracks started to propagate throughout the beam length, but it was noticed that cracks are not convergent as was reported for B1 and B3. Failure of these specimens was due to rupture of GFRP bars and debonding of GFRP bars from the concrete at the flexural zone of concrete beam specimen in addition to crushing of concrete in compression zone at top of concrete beam specimen. The first cracking load (Pcr), yield, and maximum failure measured load as well as their relative vertical deflections for all tested specimens beam were monitored and listed in Table 6, while Fig. 8 shows the observed crack pattern for the six specimens.

From previous Fig. 6, the different crack patterns and failure of modes were due to the GFRP reinforcement ratio and compressive strength of concrete. The initial cracking of beam specimens (B2 and B5) was observed in the constant moment region exactly under the applied point load. The initial cracking load in the beam specimens B3 and B6 was slightly higher than that in the beam specimens B2 and B5 due to decreasing in the GFRP-bar ratio. At the maximum load, both reinforced beam specimens (B2 and B5), (B1, and B4), and (B3, B6) recorded approximately the same amounts of cracks.

The rupture in GFRP bars at the flexural zone at the failure level of the beam was observed in tested beam specimens (B2, B3, B5, and B6) as shown in Fig. 7. Three different types of failure were observed: tensile rupture failure of GFRP bars at the flexural zone in midspan followed the failure in a concrete compressive strength of tested fully GFRP-reinforced concrete beams (B2 and B5); and tensile rupture failure of GFRP bars at the flexural zone in midspan of the beam specimen after the failure of concrete compressive strength at the top part of the tested partially GFRP-reinforced concrete beam

Table 5 Reinforcement details

\begin{tabular}{|c|c|c|c|c|}
\hline $\begin{array}{l}\text { Group } \\
\text { no. }\end{array}$ & $\begin{array}{l}\text { Beam } \\
\text { ID }\end{array}$ & $\begin{array}{l}\text { Bottom longitudinal } \\
\text { reinforcement }\end{array}$ & $\begin{array}{l}\text { Top longitudinal } \\
\text { reinforcement }\end{array}$ & $\begin{array}{l}\text { Stirrups (steel } \\
\text { bars) }\end{array}$ \\
\hline \multirow[t]{3}{*}{ Group 1} & $\mathrm{~B} 1$ & 4T10 Steel bars & 2R8 Steel bars & $6 \varphi 8 / m^{\prime}$ \\
\hline & B2 & $4 \varphi 10$ GFRP bars & $2 \varphi 8$ GFRP bars & $6 \varphi 8 / m^{\prime}$ \\
\hline & B3 & $\begin{array}{l}2 \varphi 10 \text { GFRP bars (Bottom layer) } \\
+ \\
\text { 2T10 Steel bars (top layer) }\end{array}$ & 2R8 Steel bars & $6 \varphi 8 / m^{\prime}$ \\
\hline \multirow[t]{3}{*}{ Group 2} & B4 & 4T10 Steel bars & 2R8 Steel bars & $6 \varphi 8 / m^{\prime}$ \\
\hline & B5 & $4 \varphi 10$ GFRP bars & $2 \varphi 8$ GFRP bars & $6 \varphi 8 / m^{\prime}$ \\
\hline & $\mathrm{B} 6$ & $\begin{array}{l}2 \text { 甲 } 10 \text { GFRP bars (Bottom layer) } \\
+ \\
\text { 2T10 Steel bars (top layer) }\end{array}$ & 2R8 Steel bars & $6 \varphi 8 / m^{\prime}$ \\
\hline
\end{tabular}




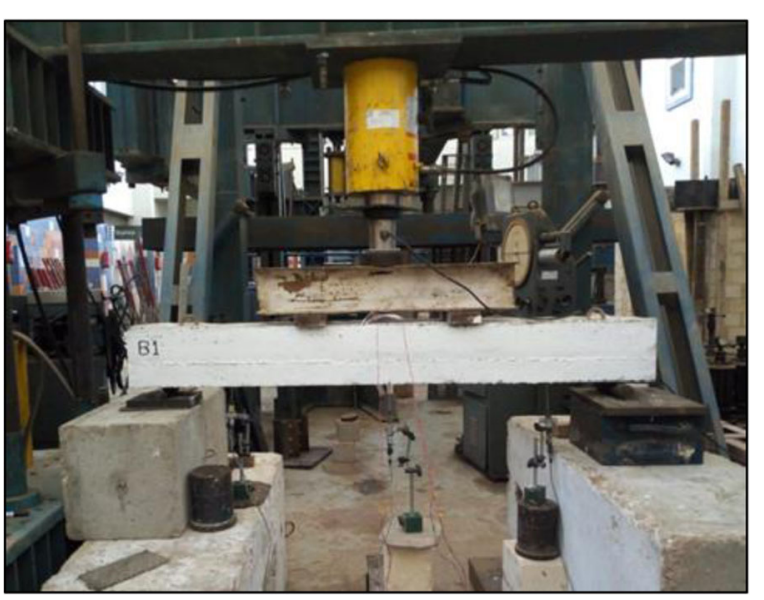

Fig. 4 Test set-up

specimens (B3 and B6). The flexure shear failure of the tested concrete beam specimens (B1 and B4) has a 0\% GFRP reinforcement ratio that was observed also.

\section{Crack width}

The crack width is an important parameter that should be investigated for measuring the performance of reinforced concrete structures where it highly affects the resistance of steel reinforcement to corrosion. Unlike structural concrete members reinforced by steel bars, the durability of concrete structure members reinforced with GFRP bars is not critically dependent on the crack width in the structural concrete members.

As previously shown in Fig. 8, the number of cracks in specimens fully reinforced by steel bars is bigger than that in specimens fully/partially reinforced by GFRP bars, while the crack width for specimens fully/partially reinforced by GFRP bars was observed to be wider than that full reinforcement with steel bars refer to the ductility of steel bar reinforcement.

\section{Load-deflection behavior}

The load of each specimen is plotted versus the corresponding deflection up to failure as shown in Fig. 10 shows the load-deflection curves for all tested beam specimens. Table 7 shows the load at the first crack, the failure load, and the maximum deflection for all specimens.

In general, the behavior of the tested specimens can be divided into two stages; the first one is referred to as a "prior to crack stage," in which the behavior of all specimens

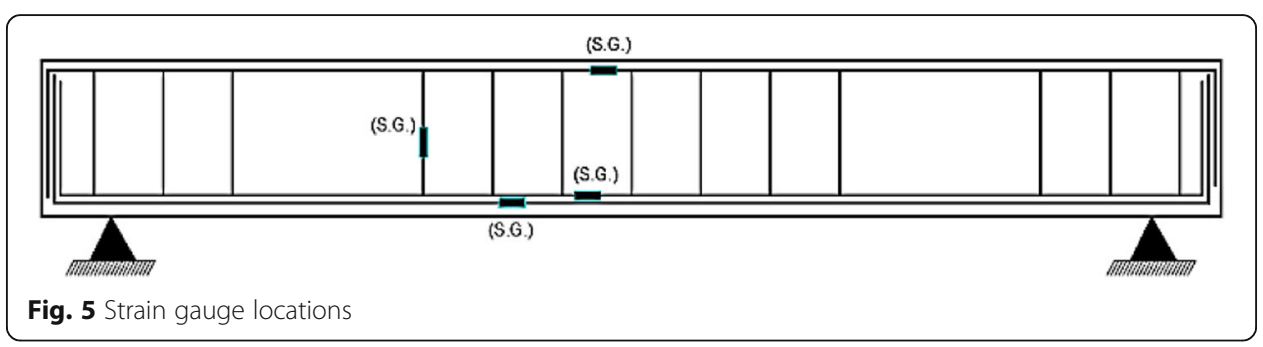


Table 6 Experimental results of tested beams

\begin{tabular}{|c|c|c|c|c|c|c|c|c|c|}
\hline $\begin{array}{l}\text { Beam } \\
\text { no. }\end{array}$ & $\begin{array}{l}P_{\mathrm{cr}} \\
\text { (ton) }\end{array}$ & $\begin{array}{l}\Delta_{c r} \\
(\mathrm{~mm})\end{array}$ & $\begin{array}{l}P_{y} \\
\text { (ton) }\end{array}$ & $\begin{array}{l}\Delta_{y} \\
(\mathrm{~mm})\end{array}$ & $\begin{array}{l}P_{\mathrm{u}} \\
\text { (ton) }\end{array}$ & $\begin{array}{l}\Delta_{u} \\
(\mathrm{~mm})\end{array}$ & $\frac{P_{c r}}{P_{u}}$ & $\begin{array}{l}\text { Modes of } \\
\text { failure }\end{array}$ & Collapse reason \\
\hline$\overline{B 1}$ & 3.50 & 4.158 & 7.98 & 10.40 & 9.8 & 26.87 & 0.357 & $\begin{array}{l}\text { Shear flexure } \\
\text { failure }\end{array}$ & Concrete crushing \\
\hline B2 & 1.80 & 1.60 & ---- & --- & 10.96 & 33.90 & 0.164 & $\begin{array}{l}\text { Flexure } \\
\text { failure }\end{array}$ & $\begin{array}{l}\text { GFRP bar rupture before } \\
\text { concrete crushing }\end{array}$ \\
\hline B3 & 1.87 & 1.24 & 7.10 & 9.50 & 10.28 & 39.20 & 0.182 & $\begin{array}{l}\text { Flexure } \\
\text { failure }\end{array}$ & $\begin{array}{l}\text { GFRP bar rupture just before } \\
\text { concrete crushing }\end{array}$ \\
\hline B4 & 4.75 & 4.62 & 10.95 & 11.56 & 12.16 & 23.93 & 0.390 & $\begin{array}{l}\text { Shear flexure } \\
\text { failure }\end{array}$ & Concrete crushing \\
\hline B5 & 1.80 & 0.68 & ---- & - & 14.22 & 32.40 & 0.126 & $\begin{array}{l}\text { Flexure } \\
\text { failure }\end{array}$ & $\begin{array}{l}\text { GFRP bar rupture before } \\
\text { concrete crushing }\end{array}$ \\
\hline B6 & 1.88 & 2.91 & 8.76 & 14.58 & 13.12 & 34.05 & 0.143 & $\begin{array}{l}\text { Shear flexure } \\
\text { failure }\end{array}$ & $\begin{array}{l}\text { GFRP bar rupture just before } \\
\text { concrete crushing }\end{array}$ \\
\hline
\end{tabular}

was similar and was approximately linear. The second stage is called the "post cracking stage," where the cracks were initiated and developed. In the latter stage, the crack propagation resulted in a decrease of the beam flexural stiffness causing a difference in the specimens' behavior.

Figures $9,10,11,12,13$, and 14 show the load versus the reinforcement strain recorded from the electrical resistance strain gauge located at the midlength of the bottom and top GFRP.

According to the strain plot curves of reinforced bars, the strain of steel bars in normal concrete compressive strength beam specimens B1 is $17.64 \%$ greater than that of steel bars in high concrete compressive strength beam specimen B4; this is attributed to the increasing in concrete compressive strength leads to a decrease in steel strain related that neutral axes of cross-section stress block. Increasing concrete compressive strength leads to an increase in tensile rupture capacity of GFRP bars, where the ultimate strain of GFRP bars in reinforced concrete beam specimen B5 is greater than the ultimate strain of GFRP bars in reinforced concrete beam specimen B2 by $33.33 \%$. As a result, when applying the GFRP bars for reinforcement, a high grade of concrete compressive strength is a suitable choice.

Regarding partially GFRP bar reinforcement in concrete beam specimens B3 and B6, it can be observed that the rupture of GFRP bars was occurred before concrete beam specimen failure due to the use of steel bars as a partial reinforcement in concrete beam specimens.

\section{Discussion}

The tested beams were divided into three groups as illustrated in Table 8. Each group has an intended purpose for testing as follows:

Group 1: Studied the effect of GFRP bars on the performance/behavior of reinforced concrete beams.

Group 2: Studied the effect of characteristic concrete compressive strength on the performance/behavior of concrete beams fully/partially reinforced with GFRP bars.

Group 3: Studied the effect of GFRP bars volume (as a reinforcement ratio) on the mode of failure and performance/behavior of reinforced concrete beams. 


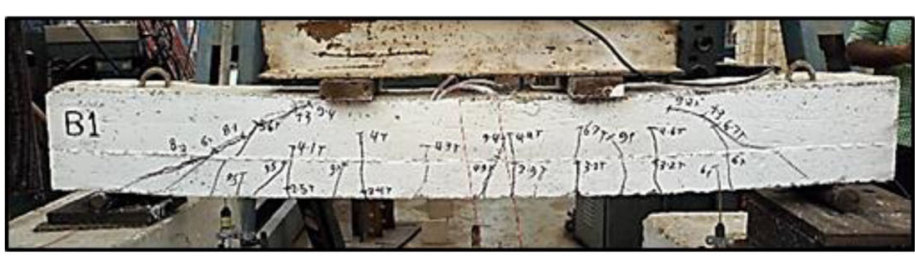

a: Crack Patterns at Failure load 9.80 ton for Tested Beam (B1)

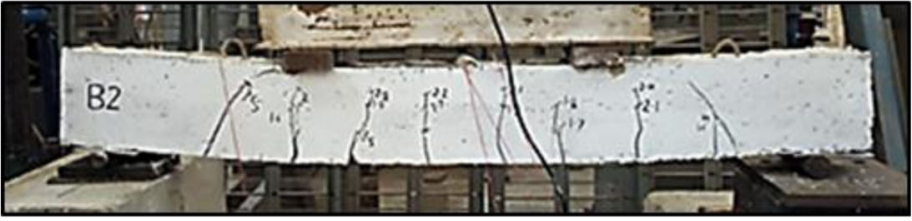

b: Crack Patterns at Failure load 33.90 ton for Tested Beam (B2)

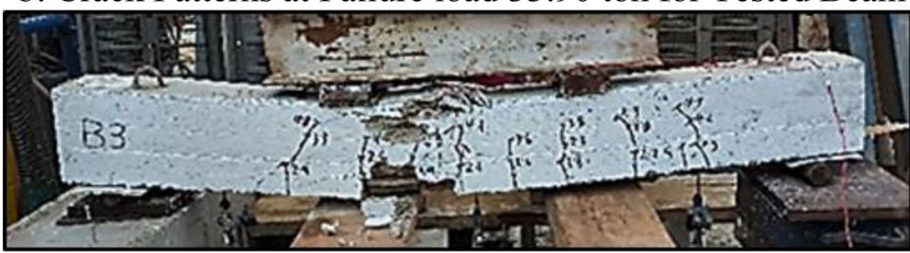

c: Crack Patterns at Failure load 39.2 ton for Tested Beam (B3)

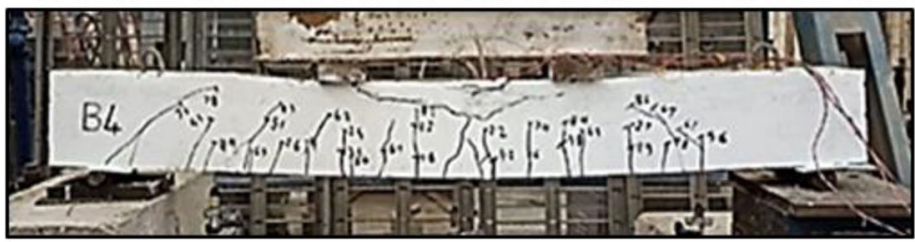

d: Crack Patterns at Failure load 23.93 ton for Tested Beam (B4)

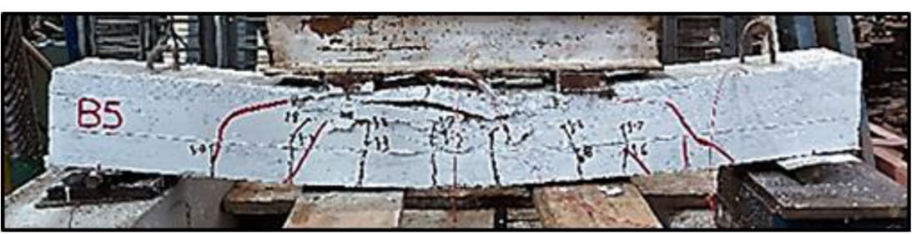

e: Crack Patterns at Failure load 32.40 ton for Tested Beam (B5)

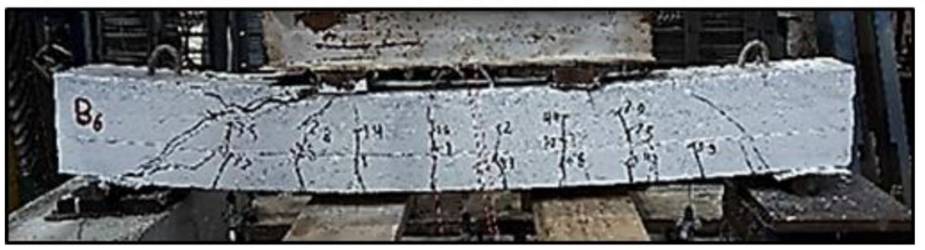

f: Crack Patterns at Failure load 34.05 ton for Tested Beam (B6)

Fig. 6 a Crack patterns at failure load 9.80 ton for tested beam (B1). b Crack patterns at failure load 33.90 ton for tested beam (B2). c Crack patterns at failure load 39.2 ton for tested beam (B3). $\mathbf{d}$ Crack patterns at failure load 23.93 ton for tested beam (B4). e Crack patterns at failure load 32.40 ton for tested beam (B5). f Crack patterns at failure load 34.05 ton for tested beam (B6). Crack patterns at failure for tested beams 


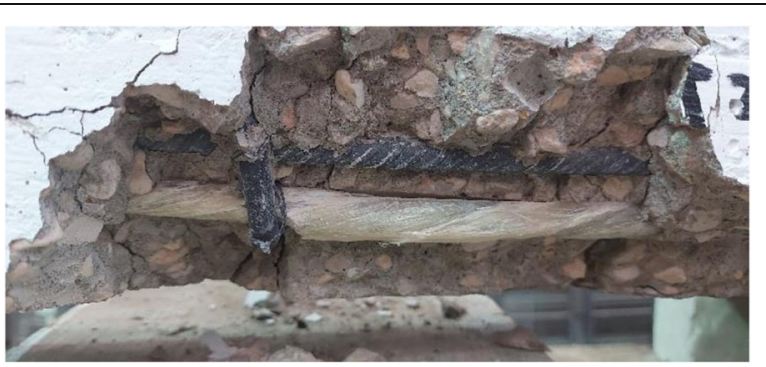

Fig. 7 Rupture of the GFRP bar at the failure of a tested beam specimen

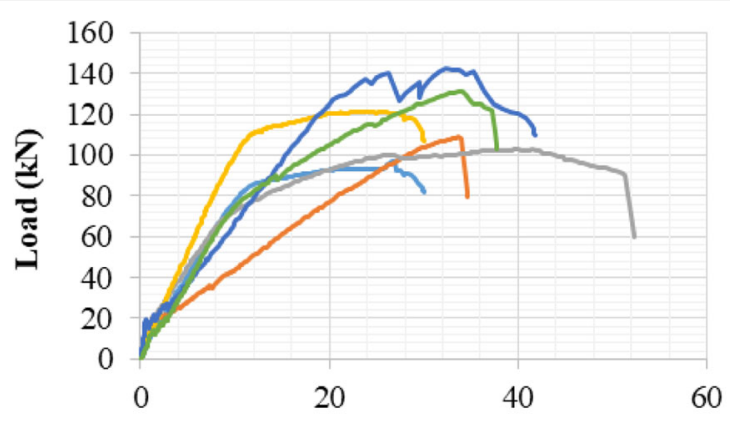

Deflection (mm)

$-\mathrm{B} 1-\mathrm{B} 2-\mathrm{B} 3-\mathrm{B} 4-\mathrm{B} 5-\mathrm{B} 6$

Fig. 8 Load-vertical deflection relationships of all tested beams

Table 7 Results of tested beams

\begin{tabular}{|c|c|c|c|c|c|c|}
\hline \multirow{2}{*}{$\begin{array}{l}\text { Beam } \\
\text { no. }\end{array}$} & \multicolumn{2}{|c|}{ Dim. (mm) } & \multirow{2}{*}{$\begin{array}{l}{ }^{*} F_{\mathrm{cu}} \\
(\mathrm{MPa})\end{array}$} & \multicolumn{3}{|c|}{ Test results } \\
\hline & $\bar{b}$ & $D$ & & ${ }^{\bar{*}{ }^{*} P_{\mathrm{u}}}$ & $\Delta \max (\mathrm{mm})$ & ${ }^{* * *} P_{\text {crack }}$ \\
\hline$\overline{B 1}$ & 150 & 200 & 346 & 97.1 & 27.12 & 22 \\
\hline B2 & 150 & 200 & 351 & 109.6 & 33.68 & 12 \\
\hline B3 & 150 & 200 & 338 & 102.8 & 41.54 & 18 \\
\hline B4 & 150 & 200 & 630 & 121.6 & 26.15 & 25 \\
\hline B5 & 150 & 200 & 652 & 142.2 & 32.4 & 18 \\
\hline B6 & 150 & 200 & 655 & 131.2 & 34.05 & 22 \\
\hline
\end{tabular}

${ }^{*} F_{\text {cu }}$ actual compressive strength concrete beams

${ }^{* *} P_{\mathrm{u}}$ ultimate load (failure load)

${ }^{* * *} P_{\text {crack }}$ initial cracking load

${ }^{* * * * *} \Delta$ max: maximum deflection at midspan 


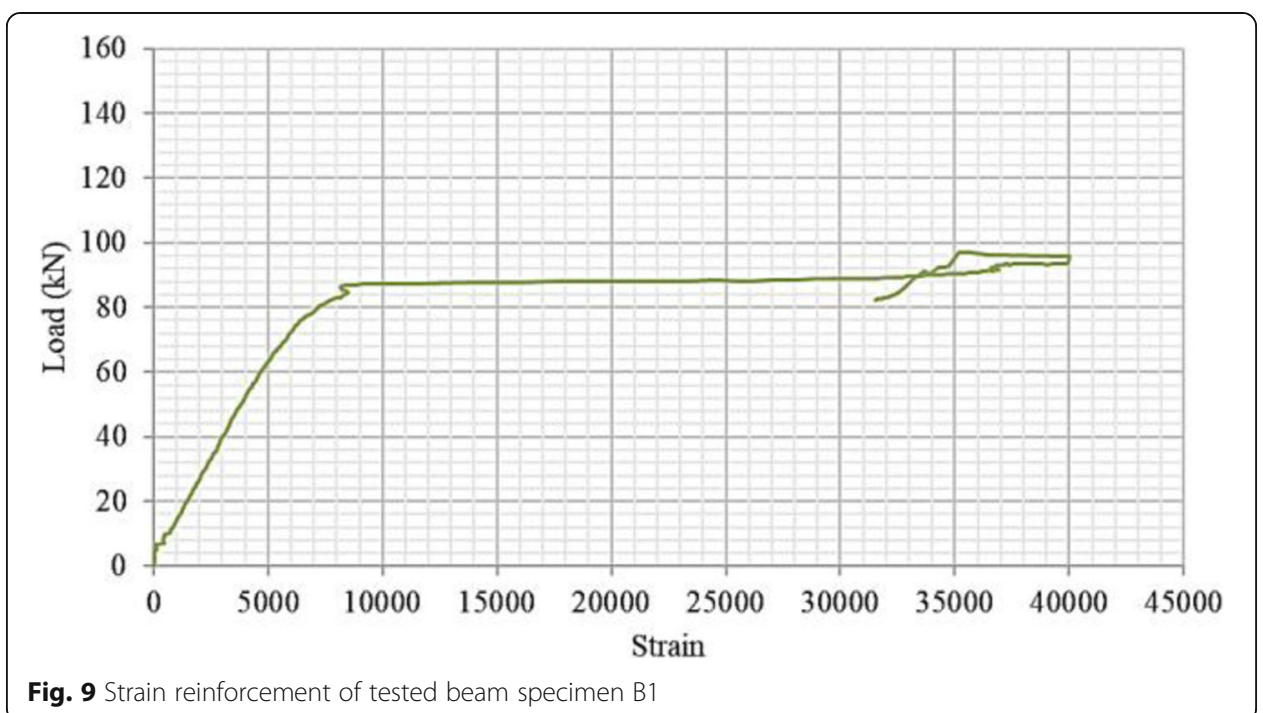

Group 1 studied the effective GFRP reinforcement on the reinforced concrete beam behavior. Generally, the tested specimens B1 and B4 (fully reinforced by longitudinal traditional steel bars) failed in flexural shear in a ductile mode of failure when compared to the specimens B2 and B5 (fully reinforced by GFRP bars) and to specimens B3 and B6 (partially reinforced by GFRP bars). This is attributed to that of the GFRP bars that possess mechanical properties different from steel bars including higher tensile strength in addition to a lower modulus of elasticity and elastic brittle stress-strain relationship. In this regard, the strain of the GFRP and steel bars was recorded, and it was found that the maximum elongation of GFRP bars was ranged approximately from 1.5 to $2 \%$, while it was reported to be in the range of 3.4 to $4.1 \%$ for the traditional steel bars.

Group 2 studies the effect of the concrete compressive strength on the reinforced concrete beam behavior that is reinforced partially and fully GFRP bars withlwithout traditional steel bar reinforcement. The behavior of specimens including the ductility,

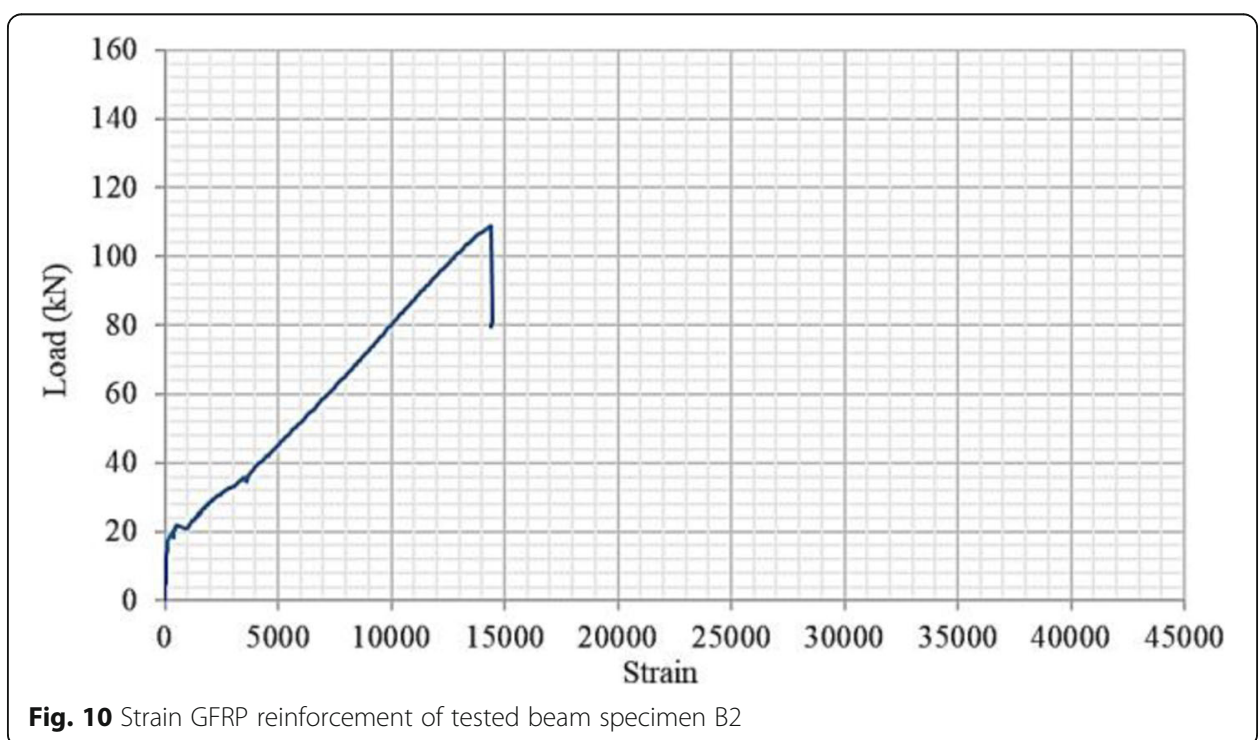




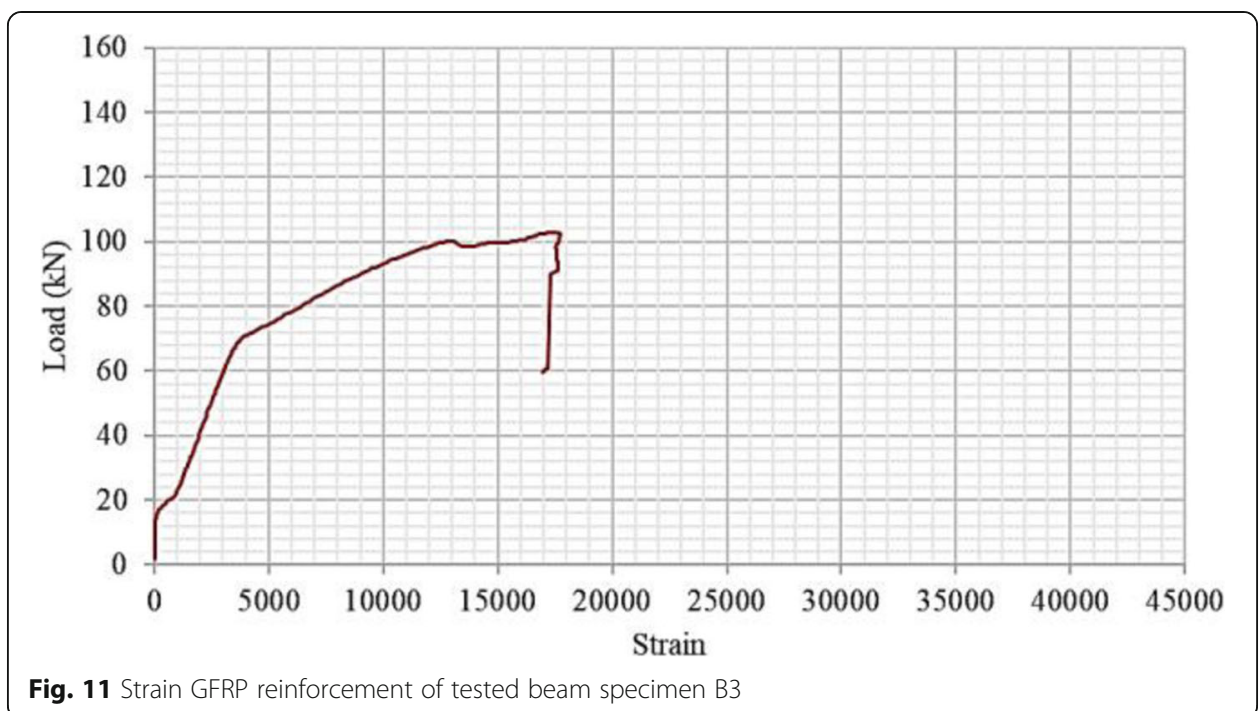

average crack width, and number of cracks was affected by the concrete compressive strength as shown in Figs. 16, 17, and 18. It was found that, as the concrete compressive strength increased from 30 to $60 \mathrm{MPa}$, the ductility decreased by $27.36 \%, 15.14 \%$, and $23 \%$ for beams fully reinforced with steel bars, fully reinforced with GFRP bars, and partially reinforced with GFRP bars, respectively.

The ability of the material to withstand permanent deformation under a tensile load without rupture was called ductility. In this study, the ductility was investigated for all tested specimens by calculating the ratio of total energy ( $\mathrm{Au}$, the area under ultimate load-deflection curve) to yielding energy (Ay, the area under yielding load-deflection curve). The yield deflection is calculated in this study as the intersection of two lines; the first line is the secant passing through the original and the point on the loaddeflection curve with $75 \%$ of the ultimate load; and the second lines are a horizontal line passing through the ultimate point on the load-deflection curve.

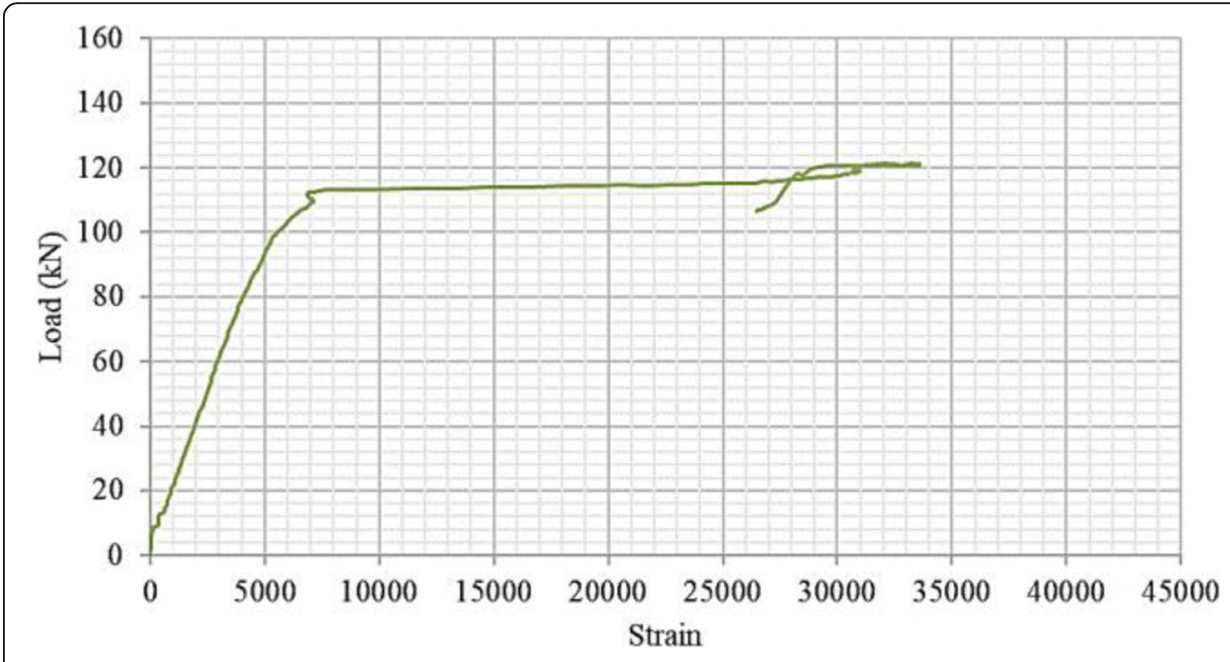

Fig. 12 Strain reinforcement of tested beam specimen B4 


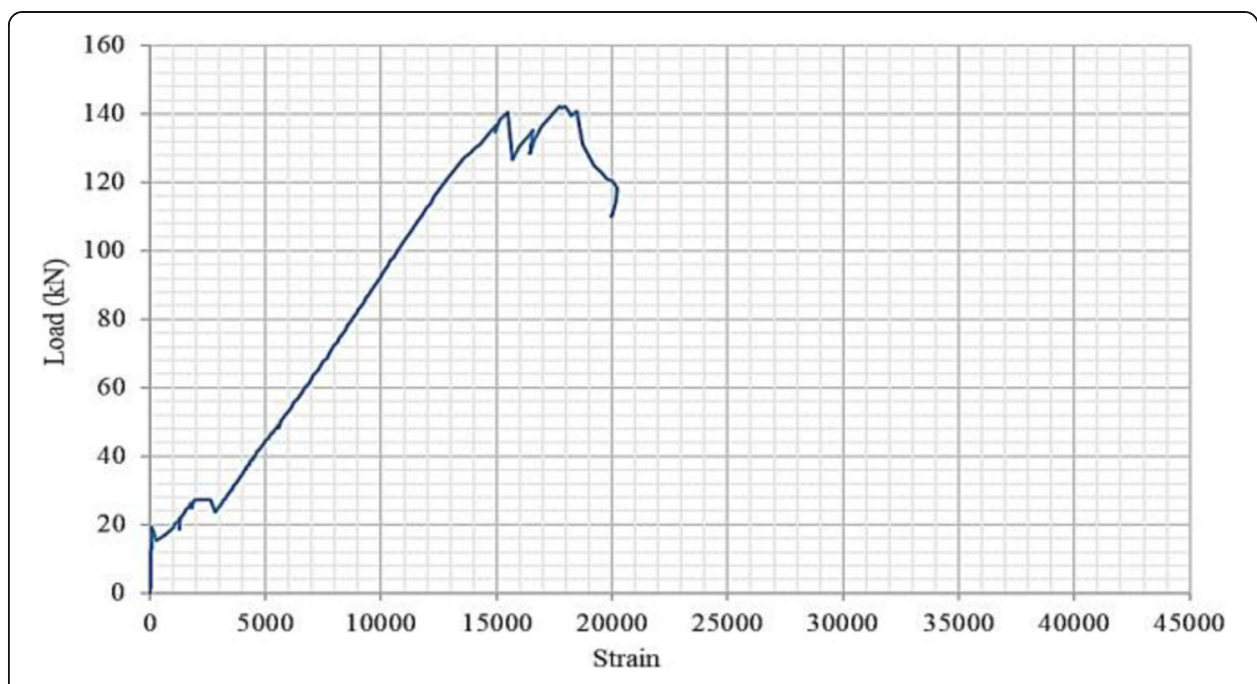

Fig. 13 Strain GFRP reinforcement of tested beam specimen B5

Specimens B1 and B4 have smaller crack widths and higher numbers of cracks when compared to specimens B2 and B5. This refers to the lower elastic modulus of GFRP bars which lead to a lower ductility and, consequently, increases the average crack width.

Using partially, steel bars with GFRP bars as flexural reinforcement were enhanced of ductility compared by fully GFRP bars as flexural reinforcement up to $47.62 \%$ increase in ductility. However, the same modes of failure and crack propagation were observed for specimens B2 and B5, for specimens B3 and B6, and for specimens B1 and B4, although the difference in concrete compressive strength.

Group 3 studies the effect of GFRP bars that reinforced the percentage on a concrete beam behavior. Decreasing in ductility of beam behavior up to $32.26 \%$ can be observed by increasing in GFRP bar reinforcement percentage with reference to the steel bar increases. Specimen B1 has a larger ductility than specimens B2 and B3 by $74.50 \%$ and 19.00\%, respectively, while specimen B4 has a larger ductility than specimens B5 and B6 by $50.40 \%$ and $12.23 \%$, respectively. This is attributed to high tensile strength with a

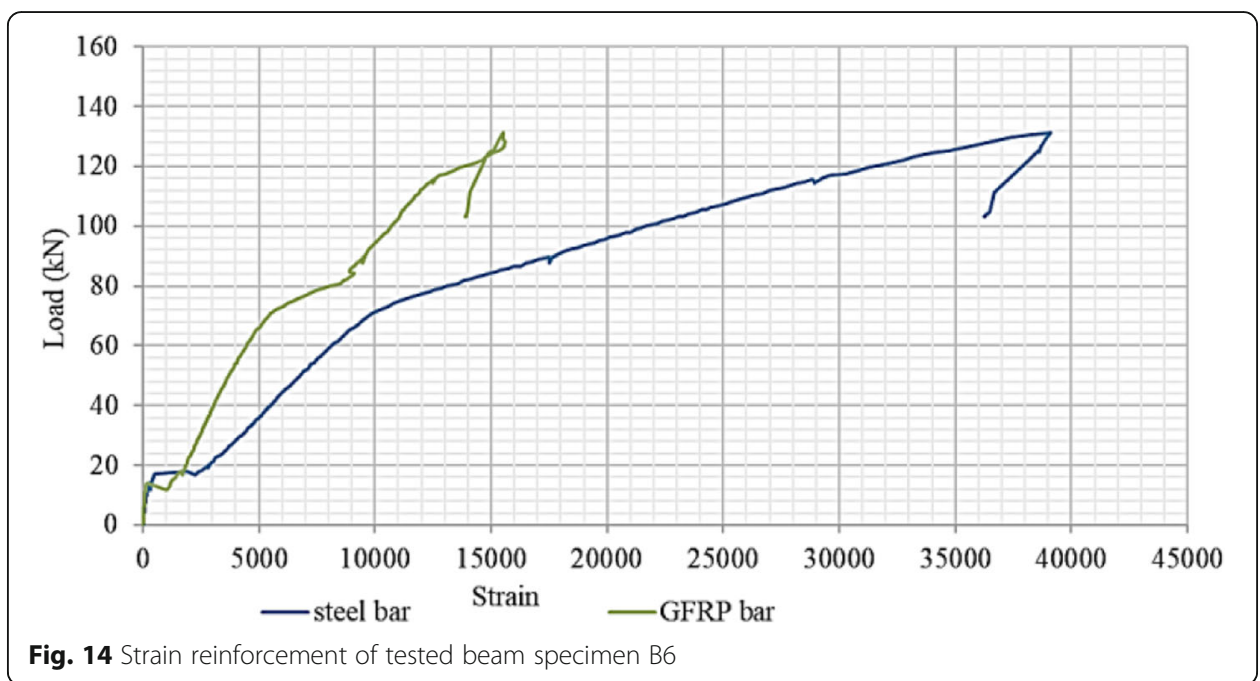




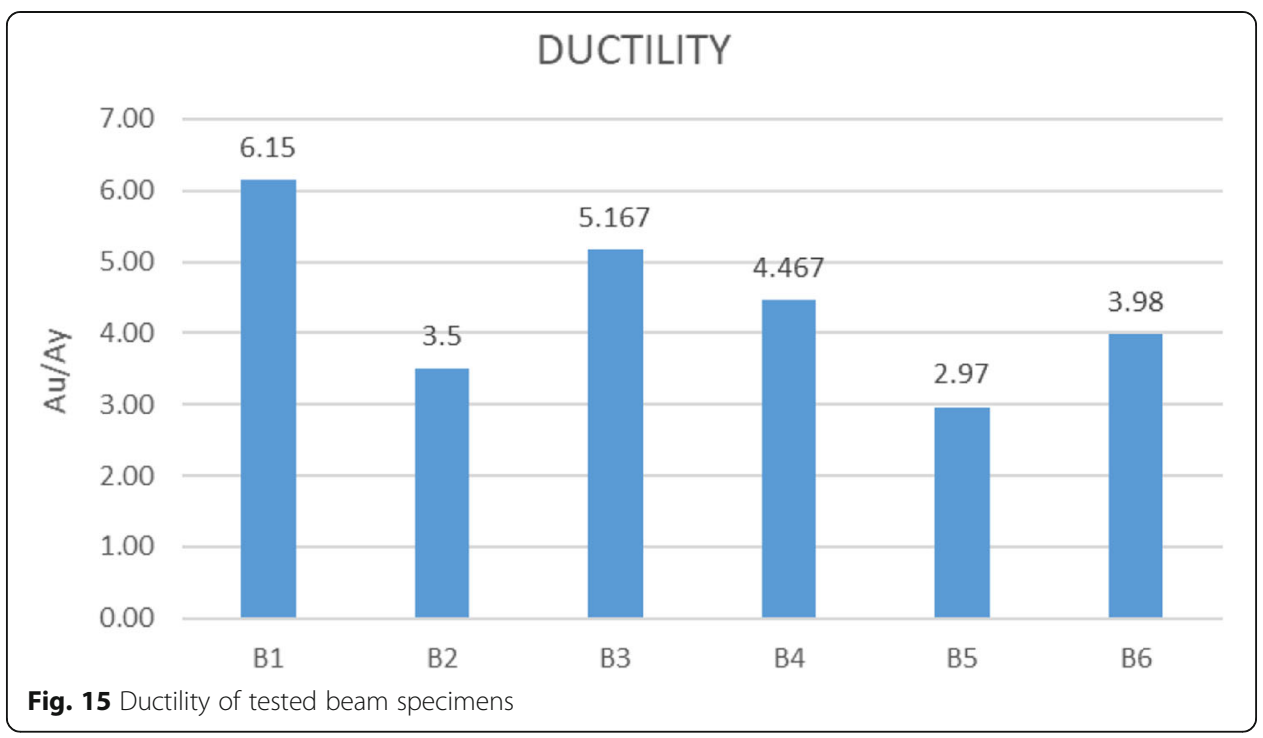

low modulus of elasticity for GFRP-bar reinforcement compared to traditional steel bars. Figure 15 represented the ductility of all tested beam specimens.

The initial and post-cracking stiffness of the tested beam was calculated based on the slope of the load-deflection curve before and after crack, respectively. And Fig. 16 shows that the initial and post-cracking stiffness of tested beam specimens.

From Fig. 16, using steel bars as a flexural reinforcement leads to an increase in the number of cracks at the flexural zone of the reinforced beam with lesser cracks width when compared with beam specimens reinforced by GFRP bars as flexural reinforcement. Increasing in GFRP ratio in reinforced concrete beams (B2 and B5) leads to decreasing in post cracking when compared with B1 and B4 by $32.84 \%$ and $35.80 \%$, respectively.

The increase in post-cracking for beam specimens B1 and B4 effecting in modes of failure and crack propagation when compared with modes of failure of remaining

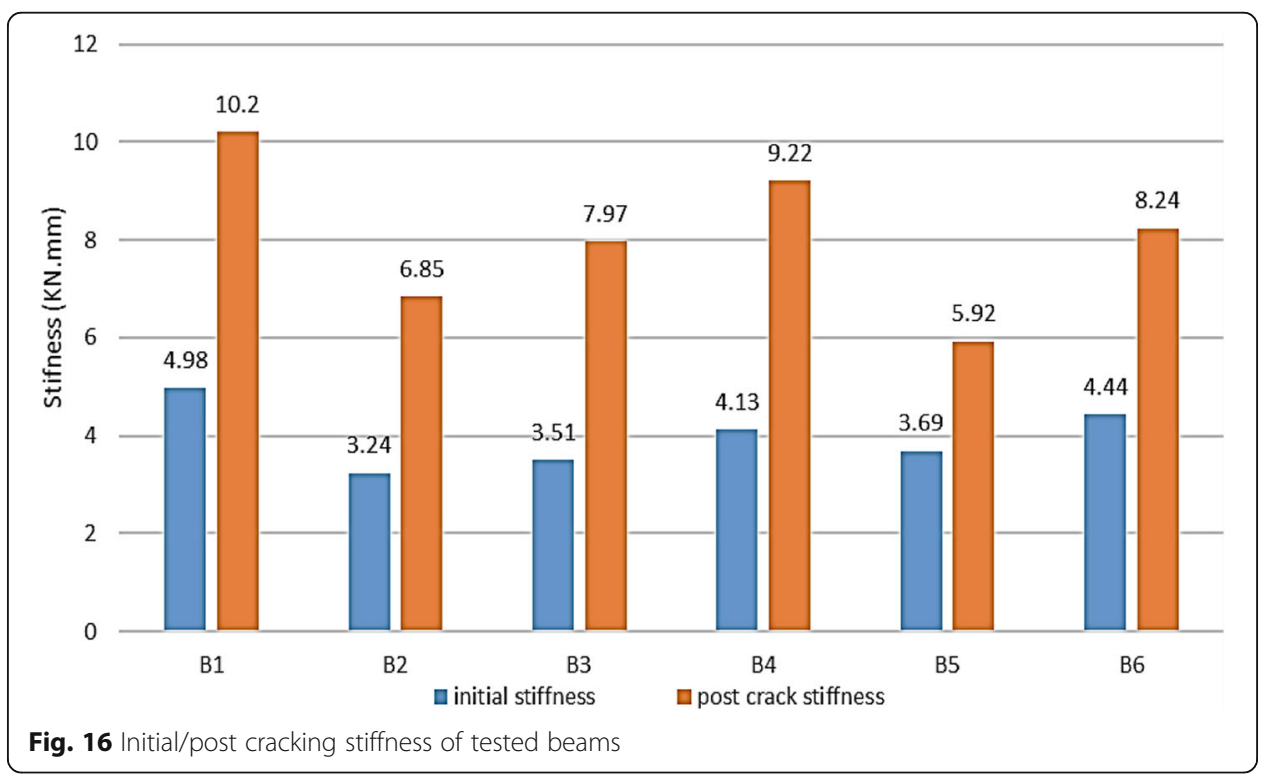




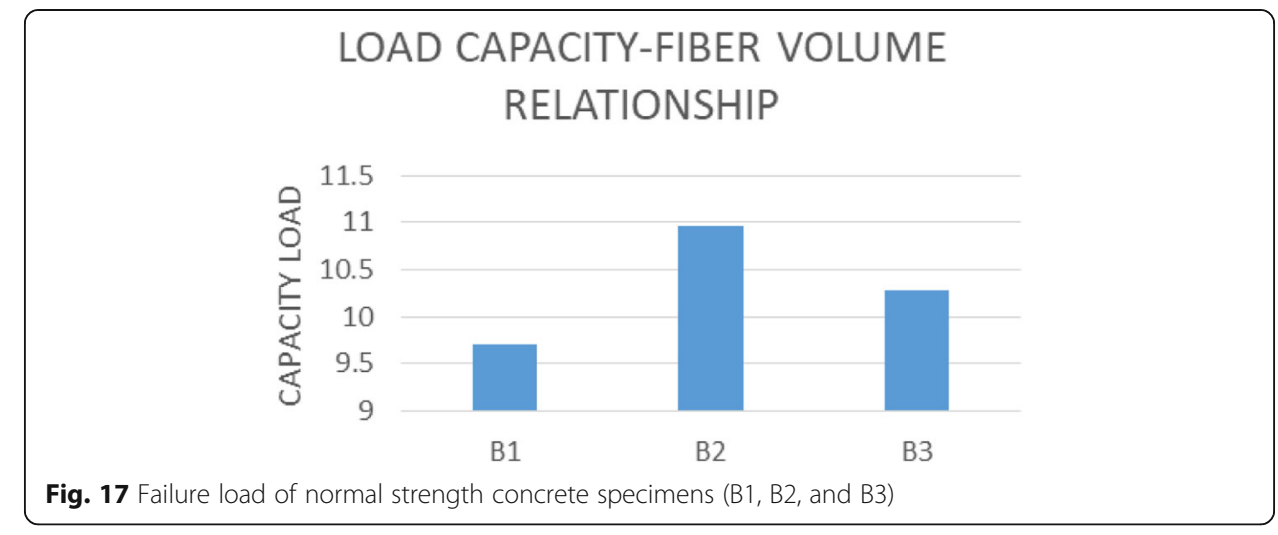

reinforced beam specimens. The concrete compressive strength had a significant effect on the initial crack. The initial cracking load increased with the increase in concrete compressive strength from 13.89 up to $26.49 \%$.

The flexural capacity of specimens B2 and B5 is higher than that of specimens B3 and B6 by $6.45 \%$ and 8.38\%, respectively, as shown in Figs. 17 and 18. It was also found higher than that of specimens B1 and B4 by $12.87 \%$ and $16.94 \%$, respectively. This is attributed to GFRP bars that resisted the additional stresses compared to the yield stresses of traditional steel bars as detailed in Tables 3 and 4.

\section{Conclusions}

From the analysis and discussion of the test results obtained from this research, the following conclusions can be drawn:

1- Increasing of GFRP reinforcement ratio can possibly change the nature of the failure from flexural shear failure (concrete beam specimens B1 and B4) to flexural failure (concrete beam specimens B2 and B5).

2- Increasing of GFRP reinforcement ratio leads to a decrease in the number of cracks with increasing in the crack width.

3- Using GFRP bar reinforcement in concrete beams was affected the stiffness of the beam specimens. Consequently, the beams with a low GFRP reinforcement ratio recorded significant deformation and post-cracking stiffness enhancement.

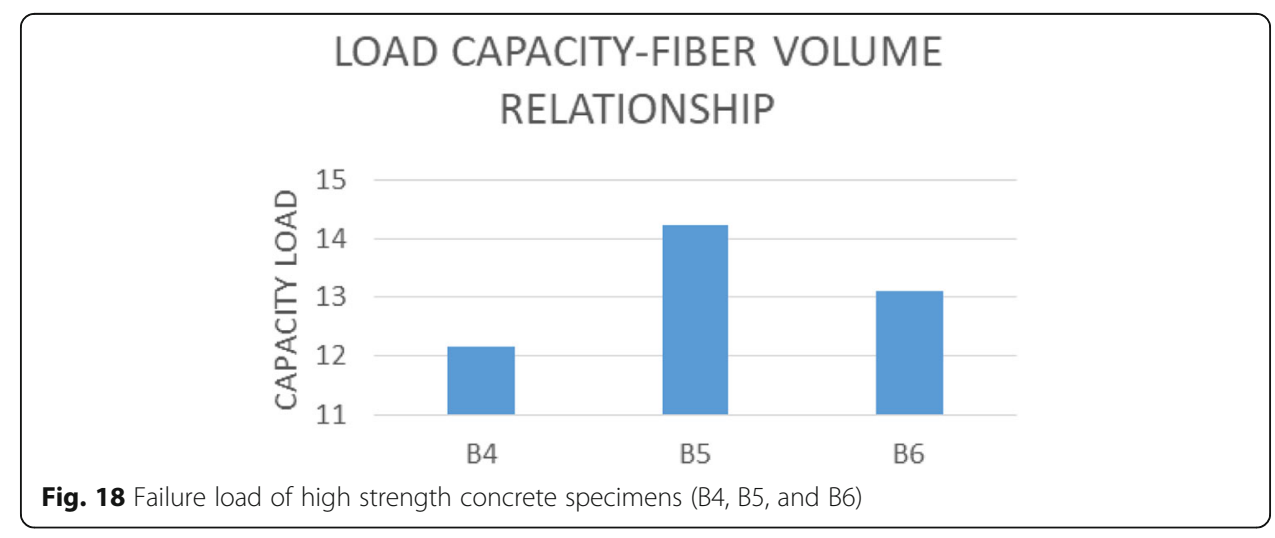


4- Beams with lower concrete compressive strength had more deflections when compared with higher compressive strength beams, and increasing in performance and compatibility of GFRP bars in high-strength concrete can be observed also.

5- Increasing concrete compressive strength and GFRP reinforcement ratio leads to decreasing in ductility up to $27.36 \%$ and $43.09 \%$, respectively.

6- The crack width was recorded a high value for reinforced concrete beam specimen with low compressive strength (B1) and recorded high values for reinforced concrete beam specimens with high GFRP reinforcement ratio B2 and B5. While a large number of cracks were recorded for the reinforced concrete beam with low strength concrete and low GFRP reinforcement ratio.

Abbreviations

GFRP: Glass fiber-reinforced polymer; FRP: Fiber-reinforced polymer; N.S.C: Normal strength concrete; H.S.C: Highstrength concrete

Acknowledgements

Not applicable.

Authors' contributions

MSM and AF participated in designing samples and pouring them into the laboratory. They tested the samples in the laboratory. They also monitored and analyzed the test results of the tested specimens, and also wrote the manuscript. All authors MSM and AF have approved the manuscript before submission, including the names and order of authors, and that all authors receive the submission and all substantive correspondence with editors, as well as the full reviews, verifying that all data, figures, and materials. Both authors have read and approved the final manuscript.

\section{Funding}

This study had no funding from any resource.

\section{Availability of data and materials}

The datasets collected and/or analyzed during the current study are available from the corresponding author on request. The corresponding author had full access to all the data in the study and takes responsibility for the integrity of the data and the accuracy of the data analysis.

\section{Declarations}

\section{Competing interests}

The authors declare that they have no known competing financial interests or personal relationships that could have appeared to influence the work reported in this paper.

\section{Author details}

${ }^{1}$ Department of Structural Engineering, Faculty of Engineering, Future High Institute of Engineering (FIEF), Fayoum, Egypt. ${ }^{2}$ Department of Concrete, Housing and Building National Research Center (HBRC), Giza, Egypt.

Received: 23 June 2021 Accepted: 23 September 2021

Published online: 01 December 2021

\section{References}

1. ACl Committee 318 (2008) Building code requirements for reinforced concrete and commentary. American Concrete Institute, Detroit

2. ACl 318 (2014) Building code requirements for structural concrete and commentary. American Concrete Institute (ACI), Farmington Hills, Ml

3. BS EN 1992 (2004) Design of concrete structures. In: Part 1-1: general rules and rules for buildings. European Committee for Standardization (CEN), Euro code 2, Brussels

4. ECP-203-2018 (2018) Egyptian code of practice for design and construction of reinforced concrete structures fourth edition.Concrete structures research institute, Housing and Building National Research Center, Giza, Egypt

5. CSA-S6-00 (2000) Canadian highway bridge design code (CHBDC). Section 16. In: Fiber reinforced structures. Canadian Standards Association, Rexdale (Canada), p 177

6. Hayder A (2003) Rasheed, Rim Nayal, Hani Melhem, Response prediction of concrete beams reinforced with FRP bars. Compos Struct 65:193-204

7. Czesław Bywalski, Michał Drzazga, Maciej Kaźmierowski, and Mieczysław Kamiński (2020) Shear Behavior of Concrete Beams Reinforced with a New Type of Glass Fiber Reinforced Polymer Reinforcement: Experimental Study. Materials 13(5):1159.

8. Ashour AF (2006) Flexural and shear capacities of concrete beams reinforced with GFRP bars. Construct Build Mater 20: 1005-1015

9. Chidananda SH, Khadiranaikar RB (2017) Flexural behaviour of concrete beams reinforced with gfrp rebars. Int J Adv Res Ideas Innov Technol 3(5):119-128 
10. Issa MS, Metwally IM, Elzeiny SM (2011) Influence of fibers on flexural behavior and ductility of concrete beams reinforced with GFRP rebars. Eng Struct 33:1754-1763

11. Shin S, Seo D, Han B (2009) Performance of concrete beams reinforced with GFRP bars. JAABE 8(1):197-204

12. DTC J (2014) Investigation of glass fibre reinforced polymer (GFRP) bars as internal reinforcement for concrete structures. Doctor of Philosophy, Department of Civil Engineering, University of Toronto

13. Goldston M, Remennikov AM, Sheikh MN (2017) Flexural behavior of GFRP reinforced high strength and ultra-high strength concrete beams. Constr Build Mater 131:606-617

14. Kim S, Kim S (2019) Flexural behavior of concrete beams with steel bar and FRP reinforcement. J Asian Archit Build Eng 18(2):89-97

15. Yang JM, Yoo DY, Shin HO, Yoon YS (2011) Flexural strength and deflection evaluation for FRP bar reinforced HSC beams with different types of reinforcing bar and fiber. J Korea Concrete Inst 23(4):413-420. https://doi.org/10.4334/ JKCl.2011.23.4.413

16. Moon DY, Oh HS, Ahn KY $(2008$, 2008) Parametric study on design variables of concrete beam reinforced with GFRP rebar using finite element analysis. J Korea Concrete Inst 20, 357(3):-367. https://doi.org/10.4334/JKCI.2008.20.3.357

17. Karayannis CG, Kosmidou P-MK, Chalioris CE (2018) Reinforced concrete beams with carbon-fiber-reinforced polymer bars-experimental study. Fibers 6:99. https://doi.org/10.3390/fib6040099

18. Ahmed HQ, Jaf DK, Yaseen SA (2020) Flexural capacity and behavior of geopolymer concrete beams reinforced with glass fibre-reinforced polymer bars. Int J Concrete Struct Mater (1976-0485) 14:460-9

\section{Publisher's Note}

Springer Nature remains neutral with regard to jurisdictional claims in published maps and institutional affiliations.

Submit your manuscript to a SpringerOpen ${ }^{\circ}$ journal and benefit from:

- Convenient online submission

- Rigorous peer review

- Open access: articles freely available online

High visibility within the field

Retaining the copyright to your article

Submit your next manuscript at $\boldsymbol{\nabla}$ springeropen.com 